\title{
Study of intestinal parasitic infections associated with HIV infection in Douala, Cameroon
}

\author{
Leopold G Lehman, Lafortune Kangam*, Eveline Nguepi, Marthe-Lilianne Mbenoun, Charles F Bilong Bilong \\ From 17th International Symposium on HIV and Emerging Infectious Diseases (ISHEID) \\ Marseille, France. 23-25 May 2012
}

\begin{abstract}
Aim
Gastrointestinal infections are common in people living with HIV. Diarrhea occurred in 30 to $90 \%$ of them. However reports on the prevalence of gastrointestinal parasites (GIP) and HIV infection are very few in Cameroon. The purpose of this study was to assess the GIP prevalence in the context of increasing availability of highly active antiretroviral therapy (HAART).
\end{abstract}

\section{Materials and methods}

A prospective study was conducted from January to December 2011 wherein stool and blood samples were collected from 201 patients in 3 hospitals of Douala. The stool samples were stained with Kinyoun and Safranin to identify coccidian oocysts. Saline preparations were used to identify ova, cysts and larva. Preparations were observed under UV light microscope CyScope ${ }^{\circledR}$ (Partec Görlitz, Germany). CD4+ T lymphocytes were counted with a flow cytometer CyFlow ${ }^{\circledR}$ (Partec Görlitz, Germany). Chi-square test was used for statistical analyses and P-value $<0.05$ was considered significant.

\section{Results}

The global prevalence of intestinal parasites was $27.8 \%$. Seventeen (48.6\%) out of 37 patients with diarrhea and $38(23.2 \%)$ out of 164 without diarrhea were parasitized. The most frequent parasites were Candida spp. (13.2\%), Cryptosporidium spp. (7.4\%) and Entamoeba histolytica/ dispar (3\%). A significant correlation $(\mathrm{p}=0.002)$ was observed between the presence of parasites and diarrhea. The highest parasite counts $(\mathrm{p}=0.035)$ and diarrhea $(\mathrm{p}<0.0001)$ were found in patients with $\mathrm{CD} 4+<200$ cells $/ \mu$ l. Srongyloïdes stercoralis, Trichuris trichuira and Isospora belli were only found in diarrheal sample.

* Correspondence: Ikangam@gmail.com

University of Yaoundé I, Douala, Cameroon

\section{Conclusions}

The overall prevalence of GIP is decreasing in Douala, probably due to the growing avaibility of HAART. This study highlights the importance of looking for intestinal parasite in HIV patient with low immunity presenting with diarrhea in Douala, which is not the case in our hospitals.

Published: 25 May 2012

doi:10.1186/1742-4690-9-S1-P48

Cite this article as: Lehman et al:: Study of intestinal parasitic infections associated with HIV infection in Douala, Cameroon. Retrovirology 20129 (Suppl 1):P48.
Submit your next manuscript to BioMed Central and take full advantage of:

- Convenient online submission

- Thorough peer review

- No space constraints or color figure charges

- Immediate publication on acceptance

- Inclusion in PubMed, CAS, Scopus and Google Scholar

- Research which is freely available for redistribution

Submit your manuscript at www.biomedcentral.com/submit
C Biomed Central 